\section{ECONOMICS}

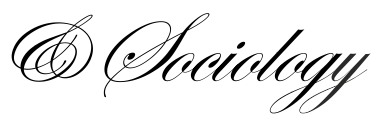

\title{
REPUTATION TO THE VICIOUS CIRCLE OF EARNINGS QUALITY AND FINANCIAL PERFORMANCE
}

\author{
Quang Linh Huynh, \\ School of Economics and Law \\ Tra Vinh University, \\ Tra Vinh, Vietnam \\ E-mail: \\ buynhquanglinb@tvu.edu.vn
}

Received: October, 2018

1st Revision: February, 2019

Accepted: May, 2019

DOI: $10.14254 / 2071-$

789X.2019/12-2/22

\begin{abstract}
This paper analyzes how the link between earnings quality and financial performance is interplayed and decides which an originating cause within the link is. It further investigates whether that connection is mediated by organizational reputation. A survey of 194 firm-year observations of Vietnamese publicly listed companies appeared on the 50 best companies list voted by Forbes Vietnam from 2012 to 2015 discovers that earnings quality plays an originating role within the vicious linkage where earlier earnings quality is a cause of current financial performance that in turn affects subsequent earnings quality. The presence of organizational reputation partially mediates the effect of earlier earnings quality on current financial performance, but it fully mediates the effect of current financial performance on subsequent earnings quality. Therefore, executive managers and accounting researchers in the world in general and in emerging economies such as Vietnam in particular should deeply consider the vicious link between earnings quality and financial performance, and the mediation of organizational reputation when analyzing earnings performance.
\end{abstract}

Keywords: Earnings quality, financial performance, organizational reputation, a vicious circle, Vietnam, the analytic model of directed graphs

\section{Introduction}

After numerous financial accounting scandals, such as those of Xerox in 2000 and Enron in 2001 or the most recent ones of Banco Espírito Santo in 2014, Dick Smith in 2016 and British Telecom in 2017, the accuracy and transparency of reported financial accounting statements have been receiving huge attention from the public (see Grasso et al., 2009; Zhatkin et al., 2017; Du \& Shen, 2018; Huynh, 2018). Given that accounting standards allow the directors of companies to flexibly practice accounting discretion over disclosed incomes, it is conventional that directors tend to manipulate earnings if there exist large conflicts of interest between them and other stakeholders (Almahrog et al., 2016). This can be of the potential to damage organizational image, brand as well as reputation, then to negatively affect upcoming financial performance, because of key stakeholders' dissatisfaction with the company (Berrone et al., 2007; Taylor \& Xu, 2010). Financial analysts and investors have therefore been becoming increasingly concerned about the quality of financial reporting (Gaio \& Raposo, 2011); of which earnings quality is a significant measure (Latif et al., 2017; Martínez-Ferrero, 2014). 
Previous research has attempted to discover the links among the quality of earnings, most importantly considered, organizational reputation and financial performance (see Huynh, 2018). The manipulation of accounting information, negatively related to earnings quality, was suggested a cause of a company's reputational harm, subsequently leading to a large decrease in its upcoming financial performance (Johnson et al., 2014; Leggett et al., 2016). In a similar line of thinking, Riahi-Belkaoui and Pavlik (1992) had also emphasized the relationships of both financial accounting transparency and financial performance with organizational reputation building and maintaining. The interplay between the quality of publicly disclosed earnings and financial performance or value has broadly been discussed in previous research (e.g. Latif et al., 2017; Warrad, 2017; Huynh, 2018; Du \& Shen, 2018). Those scholars have only focused on the causal interactions from the quality of earnings to financial performance or in the opposite influential direction.

The first trend of research recommended the quality of earnings as one of the most imperative factors to the financial effectiveness of companies (DeFond \& Park, 1997; Charitou et al., 2007; Gaio \& Raposo, 2011; Tabassum et al., 2014; Latif et al., 2017; Huynh, 2018). That tendency argued that a higher quality of reported earnings is supposed to allow companies to win public confidence and gain goodwill, so be able to achieve competitive advantages and superior subsequent performance. On the contrary, the second stream of research suggested that, companies suffering poor and weak financial performance feel more pressure to manage earnings by manipulating their financial accounting procedures resulting in a poorer quality of reported earnings (Kinney \& McDaniel, 1989; Dechow et al., 1995; Lee et al., 2006; Dechow et al., 2010; Warrad, 2017). Companies with currently positive financial performance have more resources to spend for building and improving the future reputation that enables them to behave more ethically by disclosing more real earnings (Roberts \& Dowling, 2002; Blajer-Gołębiewska \& Kozłowski, 2017). The companies less possibly manipulate earnings reporting since they are afraid of suffering reputational damage from low quality of earnings (Cao et al., 2012); as a result, the qualified financial information of earnings will be created (Du \& Shen, 2018). As argued above, the quality of earnings appears both a determinant and a consequence of financial performance, which constitutes the socalled 'a vicious circle' where these two elements are acyclically interrelated. Furthermore, that acyclic link seems to be both related to and interfered by organizational reputation (see Riahi-Belkaoui \& Pavlik, 1992; Johnson et al., 2014). Researchers have started to conduct relevant research on this interesting issue; but, to the best of the author's knowledge, none of the prior studies has investigated the mediating role of organizational reputation in the vicious link between earnings quality and financial performance.

The first purpose of this research is thus to consider the acyclic relation by establishing the notion that the quality of earnings can influence subsequent financial performance, then developing the notion that current financial performance likely affects the quality of earnings in the future, and finally exploring systematically the vicious link between the quality of earnings and financial performance.The second purpose is to link organizational reputation to both the quality of earnings and financial performance by articulating previous arguments on these links and establishing the mediating role of organizational reputation. By doing so, this work is expected to broaden the understanding of the acyclic link between earnings quality and financial performance, considering the mediation of organizational reputation. This research is the first to thoroughly investigate the acyclic association between the quality of earnings and financial performance. Another contribution is to tie the potential omitted variable 'organizational reputation' to both the quality of earnings and financial performance, and then empirically explore the mediating role of organizational reputation in this bidirectional causality. 


\section{Literature and hypotheses}

The relations among or between the quality of earnings, organizational reputation and financial performance are much more intricate than having been investigated in previous research. Earnings quality is a determinant of financial performance (Huynh, 2018), which in turn allow companies more likely to lessen earnings manipulation that is commonly used to meet stakeholders' expectations of organizational effectiveness (Du \& Shen, 2018); both of which appear linked to organizational reputation (Johnson et al., 2014; Riahi-Belkaoui \& Pavlik, 1992). Drawing on these viewpoints, the research model of this work is based on two suppositions: (1) an acyclic association likely exists between the quality of earnings and financial performance; (2) organizational reputation is a variable that likely mediates this acyclic relation. These intricate linkages are presented in Figure 1.

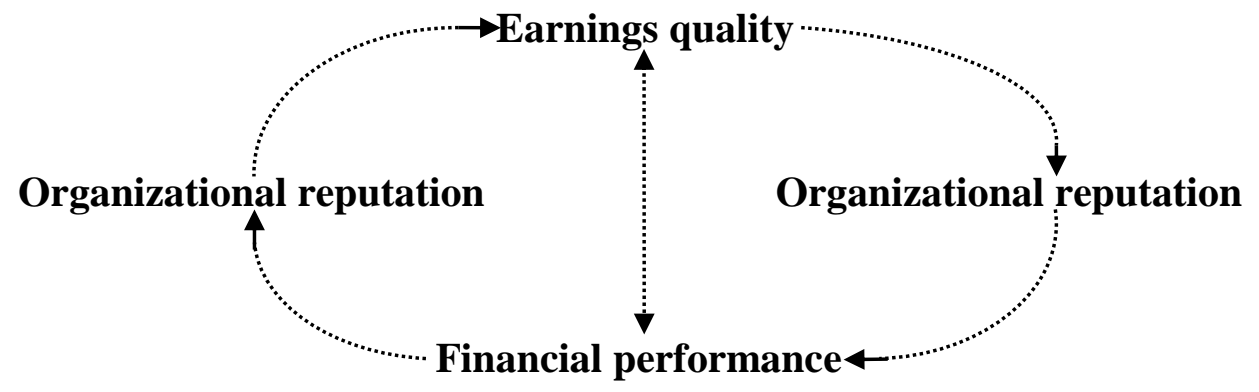

Figure 1. Research Model

\subsection{The vicious link between earnings quality and financial performance}

The security of a job is considered as one of the vital elements making stimuli or incentives for executive officers to manipulate the earnings of their companies by considering comparative financial performance for both now and future, the purpose of which is to meet forecasted earnings targets. Thus, these managers more possibly gain encouragements in promotion and premium (Machdar et al., 2017). If companies currently obtain bad financial performance and expect higher future financial performance in the future; the directors tend to 'borrow' future returns for current use; in contrast, if they currently achieve good financial performance and expect worse upcoming financial performance, their directors tend to 'put aside' some present returns for potential future use (DeFond \& Park, 1997). These lead companies to incur larger operating expenses, damage future image and reputation, which possibly reduces financial performance, suggesting that earnings quality has a positive effect on future financial performance (Taylor \& Xu, 2010). The findings from Gaio and Raposo (2011) also revealed there is a significant and positive link between earnings quality and organizational value positively associated with financial performance. Companies with good earnings quality will make goodwill for themselves, which enables the companies to gain competitive advantages, the advantages that are widely recognized as a source of better subsequent financial performance. The manipulation of earnings is a managerial activity, the aim of which is to restate current financial performance, so will offer inexact financial performance for the future (Tabassum et al., 2014); which appears useful for the present context but leads to future business issues. This can erode confidence in customers, lenders and other stakeholders. As a result, there will be a big decline in organizational competitive advantages, leading to an inferior financial performance in the future (Teoh et al., 1998). Further, according to Latif et al (2017), companies that are engaged in earning manipulation will issue their financial accounting reports with poor quality, which fail them to improve stakeholder satisfaction as well as cannot maximize their future performance. 
For the causal relationship from financial performance to earnings quality, much research has directly or indirectly discussed the link. For example, Kinney and McDaniel (1989) indicated that mistakes in financial accounting reports where earnings are presented in the bottom line are less in more profitable companies than in less profitable ones. These associations might derive from adjustments of reported income in order to satisfy firm-related parties' expectations, which needs considering when the motivations of earning manipulation are analyzed (Dechow et al., 1995; Fischer \& Verrecchia, 2000). In addition, a company's financial performance is of an important contribution to the quality of earnings (Dechow et al., 2010). Poor financial performance creates motivations for managers to undertake the manipulation of earnings that will generate low-quality financial reports.

Likewise, the results in a study of Warrad (2017) supported the causal link from return on asset as an indicator of financial performance to the quality of earnings; and another recent study took a similar line of thinking, revealing that companies with high financial performance more possibly satisfy their stakeholder's expectations without manipulating their true earnings (Du \& Shen, 2018). However, the quality of earnings goes after the financial performance and is a driver of future organizational reputation (Hammond \& Slocum, 1996). The empirical findings of Hammond and Slocum (1996) discovered that financial performance is a salient determinant of subsequent organizational reputation, which can shape the company's decisions of earnings manipulation ( $\mathrm{Lu}, 2013$ ). In the same line of thought, other previous researchers suggested that current financial performance provides companies with ample resources to maintain and improve future organizational reputation, which enables the companies to behave more responsibly and ethically to the public (Roberts \& Dowling, 2002; Blajer-Gołębiewska \& Kozłowski, 2017). This implies that the companies likely issue earnings reports with higher quality to avoid reputational damage (Cao et al., 2012).

Besides, the manipulation of earnings is widely acknowledged as a socially irresponsible behavior (Almahrog et al., 2016). Taking this stance, Choi et al. (2013) contended that companies who make a commitment to socially responsible actions are likely to act in a more socially responsible manner for the disclosure of earnings and conform to more reliable and transparent reports of earnings. These companies can also attain more satisfaction of key stakeholders, which in turn, improve future organizational reputation and financial performance (Berrone et al., 2007). Based on the instrumental stakeholder theory, the viewpoint above suggests that managerial ethics implies good relations to relevant stakeholders that will lead to a more improved financial performance in the future (Russo \& Fouts, 1997). In contrast, the stand based on slack resources theory argued that financial performance leads to an ampleness of resources for companies to take into account more socially responsible behaviors in the future and so pay more attention to the quality of earnings (Surroca et al., 2010; Warrad, 2017). In summary, it could suggest the following Hypothesis 1: the quality of prior earnings likely decides current financial performance, which in turn affect the quality of subsequent earnings.

\subsection{The intervention of organizational reputation in the vicious link}

On the one hand, organizational reputation is not only a cause of earnings quality (see Luchs et al. 2009; Ferry et al., 2017; Huynh, 2018), but also a consequence of prior earnings quality (see Kaplan \& Ravenscroft 2004; Martínez-Ferrero \& Garcia-Sanchez, 2016). On the other hand it is considered as having an effect on subsequent financial performance (see Surroca et al., 2010; Gatzert, 2015; Blajer-Gołębiewska \& Kozłowski, 2017), but as being affected by previous financial performance (see Hammond \& Slocum, 1996; Roberts \& Dowling, 2002; Liu et al., 2016). Based on the perspective of Cao et al. (2012), the directorial boards' concerns of organizational reputation could lead to their corresponding reactions in 
management, the importance of which is to control the manipulating probability of financial accounting information. Previous empirical results reported that the establishment and extension of organizational reputation possibly influence behavior as well as attitude in executive directors and financial accounting experts, urging them to take more ethical actions where their companies highly enjoy sustainable performance instead of short-term benefits (e.g. Fich \& Shivdasani, 2007; Jackson, 2005; Blajer-Golebiewska, 2014). Additionally, the role of organizational reputation in enabling companies to generate high-quality reported earnings is also emphasized in other studies on earnings and reputation (Ferry et al., 2017). The organizational reputation of a company likely triggers appropriate actions in management leading to a better quality of reported earnings; since the company would like to pursue the objective of maintaining and enhancing its reputation (see Luchs et al. 2009; Huynh 2018).

Conversely, organizational reputation is broadly accepted contingent on various managerial behaviours such as the manipulation of earnings closely linked to earnings quality (see Rodriguez-Ariza et al., 2016; Martínez-Ferrero \& Garcia-Sanchez, 2016). A company's apparent disclosure of financial reports will help its stakeholders avoid the company's financial information asymmetries, which likely improves confidence among them. It can enhance organizational image leading to higher organizational reputation in the future (Martínez-Ferrero et al., 2016, Rodriguez-Ariza et al., 2016). The magnitude of earnings manipulation of the company is inversely proportional to business reputation (MartínezFerrero \& Garcia-Sanchez, 2016). In addition, Kaplan and Ravenscroft (2004) indicated that, the manipulation of reported earnings imposes a potentially negative influence on the building and maintaining of potential organizational reputation.

Anchored on the resource-based view of the organization, it could assert that by establishing close relation to key stakeholders, a company likely builds up some intangible assets such as organizational reputation to make wise use of its resources, which therefore help gain competitive advantages enabling the company to outperform competitors in its business environment, which will result in high effectiveness, profitability and earnings growth that could in turn generate another improvement of future organizational reputation (Roberts \& Dowling, 2002; Blajer-Gołębiewska \& Kozłowski, 2017). Establishing a good organizational reputation guarantees stakeholders' continuous involvement in business; because superior organizational reputation of a company over rivals could lead it to draw the best potential workers, enhance their commitment, develop consumers' loyalty as well as bargain with lenders or suppliers at the best conditions (see Surroca et al., 2010). All of them possibly create competitive advantages that are considered important elements to improve financial performance (see Ma, 2000; Gatzert, 2015). Furthermore, drawing on the managerial viewpoint, Ali et al. (2015) stressed the importance of organizational reputation and contended that organizational reputation is widely acknowledged as an essential source of competitive advantage and as an important intangible asset that can create firm value, so obtain enhanced financial performance. A company's good reputation could motivate shareholders and other stakeholders to accept suitable behaviors, which result in better financial effectiveness (Blajer-Golebiewska, 2014; Blajer-Gołębiewska \& Kozłowski, 2017).

Likewise, many studies regarded organizational reputation as a vital indicator of the intangible resource helping to differentiate between an organization and others, which creates competitive advantages as a source of improved financial performance (e.g. Graham \& Bansal, 2007; Liu et al., 2016). In contrast, financial performance provides the company a financial resource to support social responsibility to the stakeholders, which enhances future organizational image and trademark that are essentials of organizational reputation (Surroca et al., 2010), as the stakeholders' reaction to the social responsibility can affect their perception of the company, from which organizational reputation is gradually established (Roberts \& Dowling, 2002). A company's poorly perceived social responsibility likely prevent the 
company from having a loan capital at the best cost of debt, e.g. the best rate of interest; it can suffer worse financial performance in future (Hammond \& Slocum, 1996). This study bases the research model on the discussions above, which hypothesizes that organizational reputation, an important driver of an organization's competitive advantage, could be an underestimated variable that can help explain more deeply the interplay between financial performance and earnings quality that is related to managerial behaviours.

As argued above, a company's low manipulating behaviour in reported earnings may enhance its reputation, which likely leads to competitive advantages, and therefore it likely achieves good subsequent financial performance. Good financial performance can be more investment to expand future reputation that tends to control earnings manipulating behaviors strictly. Additionally, Baron and Kenny (1986) suggested the conditions where a mediating influence can be present as follows: (1) the causal variable is confirmed a potential determinant of the outcome variable and a third variable; (2) the third variable explains the outcome variable. The synthesis of the above-mentioned arguments can propose the following Hypothesis 2: organizational reputation likely mediates the vicious relation between financial performance and earnings quality in both directions.

\section{Methodological approach}

\subsection{Measurements}

Organizational reputation (ORE): This measurement is based on the ranking levels evaluated by Forbes Vietnam. The list of the 50 best publicly listed companies employed the evaluating procedures based on the standards which Forbes used worldwide, taking into consideration the specific basics of Vietnam's business environment. The voted companies were ranked from the poor (assigning 50) to the excellent (assigning 1). Financial performance (OFP): This research drew on Surroca et al. (2010) to use Tobin's q ratio as a proxy for financial performance. Tobin's q ratio is measured by dividing the sum of the total equity market value and total liabilities book value by the sum of the total equity book value and total liabilities book value of the company, adapted from Latif et al (2017).

Earnings quality (QEA): This construct is not measured directly, so several previous studies have proposed various proxies for the quality of earnings (Francis et al., 2004; Dechow et al., 2010; Lyimo, 2014; Gaio \& Raposo, 2014); most of which just drew on instinctive and reasonable notions of required characteristics of a financial accounting structure (Huynh 2018). While Lyimo (2014) and Pagalung and Sudibdyo (2018) evaluated earnings quality with four items and Latif et al. (2017) evaluated earnings quality with five items; but other scholars measured it with seven items (e.g. Francis et al., 2004; Gaio \& Raposo, 2014). These proxies are aimed to confine the same underlying measurement to which they are related. However, that can raise the concern about what measurement to employ a decisive research design issue, and probably affect the outcomes. Unluckily, Perotti and Wagenhofer (2014) stressed that very little instruction on how suitable the items forming earnings quality are and what is the best measurement should be applied in a specific situation that has been given. Those researchers synthesized the literature on the earnings quality measures and suggested six accounting-based items and two market-based items form the quality of earnings, which are supposed to be the most appropriate. This research draws upon the measurements suggested by Perotti and Wagenhofer (2014) to measure earnings quality with the following eight items. Two items are for 'Time-series Measure' (Persistence and Predictability); two items for 'Smoothness Measures' (Standard deviation smoothness and Correlation smoothness); two items for 'Accruals Measures' (Abnormal accruals and Accruals quality); and two items for 'Value Relevance Measures' (Earnings response 
coefficient and Value relevance). Where: (1) Persistence (QEA1) is $\alpha$ of NIBE $_{t}=\delta+\alpha \mathrm{NIBE}_{\mathrm{t}}$ $1+\mathrm{u}$; (2) Predictability (QEA2) is $\mathrm{R}^{2}$ of $\mathrm{NIBE}_{\mathrm{t}}=\delta+\alpha \mathrm{NIBE}_{\mathrm{t}-1}+\mathrm{u}$; (3) Standard deviation smoothness (QEA3) is Standard deviation ratio $\sigma\left(\mathrm{NIBE}_{\mathrm{t}}\right) / \sigma\left(\mathrm{CFO}_{\mathrm{t}}\right)$; (4) Correlation smoothness (QEA4) is Correlation $\rho\left(\mathrm{ACC}_{\mathrm{t}}, \mathrm{CFO}_{\mathrm{t}}\right)$; (5) Abnormal accruals (QEA5) is Negative absolute value of residual (e) of $\mathrm{ACC}_{\mathrm{t}}=\beta_{0}+\beta_{1}\left(\Delta \mathrm{REV}_{\mathrm{t}}-\Delta \mathrm{AR}_{\mathrm{t}}\right)+\beta_{2} \mathrm{PPE}_{\mathrm{t}}+\mathrm{e}$; (6) Accruals quality (QEA6) is Negative standard deviation of residual $(\varepsilon)$ of $\mathrm{CACC}_{\mathrm{t}}=\beta_{0}+$ $\beta_{1} \mathrm{CFO}_{\mathrm{t}-1}+\beta_{2} \mathrm{CFO}_{\mathrm{t}}+\beta_{3} \mathrm{CFO}_{\mathrm{t}+1}+\varepsilon$; (7) Earnings response (QEA7) is $\alpha$ of $\mathrm{RET}_{\mathrm{t}}=\delta+\alpha \mathrm{NIBE}_{\mathrm{t}} /$ $\mathrm{P}_{\mathrm{t}}+\zeta$; (8) Value relevance (QEA8) is $\mathrm{R}^{2}$ of $\mathrm{RET}_{\mathrm{t}}=\delta+\alpha \mathrm{NIBE} / \mathrm{P}_{\mathrm{t}}+\zeta$, * Note: NIBE, CFO, ACC, CACC, PPE, $\triangle \mathrm{REV}, \triangle \mathrm{AR}, \mathrm{RET}$ and $\mathrm{P}$ are adapted from Perotti and Wagenhofer (2014).

Control variables: The control variables, entered to control potential effects on earnings quality, financial performance and organizational reputation, are size, liquidity, leverage and capital intensity of the company, adapted from previous studies (Latif et al., 2017; Sarun, 2016; Surroca et al., 2010; Roberts \& Dowling, 2002; Charitou et al., 2007; Cao et al., 2012; Ali et al., 2015; Martínez-Ferrero, 2014). Size is measured as the logarithm of the total asset book value (FSI). Liquidity is a ratio of the total current assets to the total current liabilities (FLI). Leverage is a ratio of the total debt to the total equity book value (FLE). Capital intensity is a ratio of the total asset book value to the total sales (FCI).

\subsection{Data collection}

Like other Communist nations after the Cold War, the centralized economy of Vietnam lost the driving force for dynamic and sustainable development. Since 1986, Vietnam has undertaken its reform of Doi Moi to change from a centralized economy to a socialist-oriented market economy (Le et al., 2006). Additionally, as Schwab (2017) reported, Vietnam has become an attractive destination for foreign investment and can become the world's 20th-largest economy by the year 2050. In spite of economic success through the period of Doi Moi, there have still been issues, which concern numerous policy analysts and researchers about the recent economic slowdown in Vietnam. It is necessary to conduct research related to the business operation, such as financial performance, the management of earnings, organizational reputation, etc. However, such topics in transition economies including Vietnam are under-considered (Dut, 2015). Hence, for advancing the understanding of that research void, the population for this research was selected to be the companies being present in the list of the 50 best Vietnamese publicly listed companies elected by Forbes Vietnam. For financial performance (OFP), the data was collected in yeart $\left(\mathrm{OFP}_{\mathrm{t}}\right)$. For organizational reputation (ORE), there were two variables in yeart $\left(\mathrm{ORE}_{t}\right)$ and year $\mathrm{r}_{t+1}$ $\left(\mathrm{ORE}_{\mathrm{t}+1}\right)$. To measure earnings quality $(\mathrm{QEA})$, this research used two measured variables: QEA $_{t-1}\left(\right.$ year $\left._{t-1}\right)$ and QEA $_{t+1}\left(\right.$ year $\left._{t+1}\right)$; but some dimensions of QEA $_{t+1}$ appeared in year $r_{t+2}$. Hence the votes during the last five years from 2012 to 2015 were selected (the beginning year was chosen 2012 because Forbes Vietnam started to vote Vietnamese publicly listed companies for the first time in 2012). Overall, each firm-year case was collected the data in four years ( year $_{t-1}$, year $t_{t}$, year $t_{t+1}$ and year ${ }_{t+2}$ ) and $t$ ranged from 2012 to 2015; it therefore consisted of 200 firm-year cases in total. The estimation of the QEA dimensions took a rolling 6-year period; as a result, the data that was needed collecting to calculate earnings quality (QEA) occurred over a 13-year period from 2005 to 2017. Of those selected 200 firm-year cases, there were only 194 usable firm-year observations. This number of observations meets the sample size stipulated by Hair et al (2012). The statistics of the final research sample is shown in Table 1. The largest number of the selected observations belonged to the sector of construction and construction materials, making up $16.49 \%$ with 32 observations. The second was belonging to the sector of food, accounting for $14.95 \%$ with 29 observations; followed by 
the sector of insurance, finance and banking (13.92\% with 27 observations). The least number belonged to the four sectors of seed trading and distribution, hotels and building management, fisheries, and garment with 3 observations per sector, accounting for $1.55 \%$ separately. The other sectors make up from $2.05 \%$ with 4 observations to $9.79 \%$ with 19 observations.

Table 1. Profile of the final research sample

\begin{tabular}{lcc}
\hline \multicolumn{1}{c}{ Business sectors of companies } & Number of firm-year observations & Percentage \\
\hline Food & 29 & $14.95 \%$ \\
Natural rubber, fertilizer and chemicals & 19 & $9.79 \%$ \\
Oil/ gas products, equipment and services & 14 & $7.22 \%$ \\
Pharmaceuticals and health equipment & 12 & $6.19 \%$ \\
Real estate & 5 & $2.57 \%$ \\
Software, telecommunication and retail & 4 & $2.05 \%$ \\
Insurance, finance and banking & 27 & $13.92 \%$ \\
Construction and construction materials & 32 & $16.49 \%$ \\
Warehouse and logistics & 9 & $4.64 \%$ \\
Seed trading and distribution & 3 & $1.55 \%$ \\
Hotels and building management & 3 & $1.55 \%$ \\
Fisheries & 3 & $1.55 \%$ \\
Transportation, package and cleaning & 11 & $5.67 \%$ \\
Stationery and family appliances & 7 & $3.61 \%$ \\
Garment & 3 & $1.55 \%$ \\
Other sectors & 13 & $6.70 \%$ \\
\hline Total & 194 & $100.00 \%$ \\
\hline Source: $A u t h o r$
\end{tabular}

Source: Author's calculations based on the collected data

\subsection{Analytic procedures}

Following Huynh (2015), this study tested the vicious link using the modern analytic model of directed graphs. Firstly, the advanced model of directed graph searches with the PC algorithm was applied to explore the fundamental relations and then to extract and decide the appropriate directions of the acyclic models. The model of directed graph searches is the algorithm's estimate of the dependence arrangement that generated the research data, which differentiate superior from inferior effects in the acyclic research model. Afterward, the advanced model of directed acyclic graphs with SEM parametric estimation was used to estimate the coefficients along pathways, the values of which are quite the same as the true coefficients of the parameters.

The mediation hypothesis was examined applying the analytic technique proposed by Sobel (1982) and Baron and Kenny (1986), the procedures of which include three steps. The first step was to estimate financial performance on earnings quality and control variables to confirm that the causal link between earnings quality and financial performance was statistically significant. The second step was to estimate organizational reputation on earnings quality and control variables to confirm that earnings quality significantly affected organizational reputation. The third step was to regress financial performance on organizational reputation, earnings quality and control variables to confirm that organizational reputation was a significant cause of financial performance. Then the whole procedures repeated similarly, but with financial performance and earnings quality interchanged. 


\section{Empirical results}

\subsection{Scale reliability}

There are two latent constructs in the research model, the variables of earnings quality in year $_{t-1}$ and year $r_{t+1}$. They were thus assessed for scale consistency, using the reliability analyses. The results are displayed in Table 2. For the construct of earnings quality in year $\mathrm{t}_{\mathrm{t}-1}$, the total correlations of items varying from 0.528 to 0.734 are all larger than 0.5 , the minimum preferable threshold; moreover, the Cronbach's Alpha achieves 0.883, satisfying the least limit of 0.7 (Hair et al. 2012). In addition, the Cronbachs' Alphas if item deleted ranging from 0.859 to 0.880 are all under the value of 0.883 , meeting the condition suggested by Hair et al. (2012). For the construct of earnings quality in year ${ }_{t+1}$, the analyses obtained similar results. It can then suggest that all these measurements are internally reliable. Then, this research applied the extraction method of principal component analysis with varimax to compute composite proxies of earnings quality in year $\mathrm{t}_{\mathrm{t}-1}$ and year $\mathrm{r}_{\mathrm{t}+1}\left(\mathrm{QEA}_{\mathrm{t}-1}{ } \mathrm{QEA}_{\mathrm{t}+1}\right)$.

Table 2. Scale reliability results for 'Earnings quality'

\begin{tabular}{cccc}
\hline Manifest variables & Item-total Correlation & Cronbach's $\alpha$ if Item Deleted & Cronbach's $\alpha$ \\
\hline QEA $1_{\mathrm{t}-1}$ & 0.558 & 0.877 & \\
QEA $\mathrm{t}_{\mathrm{t}-1}$ & 0.729 & 0.860 & \\
QEA $3_{\mathrm{t}-1}$ & 0.528 & 0.880 & 0.883 \\
QEA4 $\mathrm{t}_{\mathrm{t}-1}$ & 0.698 & 0.863 & \\
QEA5 $5_{\mathrm{t}-1}$ & 0.636 & 0.870 & \\
QEA6 $\mathrm{t}_{\mathrm{t}-1}$ & 0.734 & 0.859 & \\
QEA $7_{\mathrm{t}-1}$ & 0.659 & 0.867 & \\
QEA $8_{\mathrm{t}-1}$ & 0.659 & 0.867 & \\
\hline QEA $1_{\mathrm{t}+1}$ & 0.655 & 0.852 & \\
QEA $2_{\mathrm{t}+1}$ & 0.666 & 0.851 & \\
QEA ${ }_{\mathrm{t}+1}$ & 0.605 & 0.857 & \\
QEA $4_{\mathrm{t}+1}$ & 0.559 & 0.863 & \\
QEA $5_{\mathrm{t}+1}$ & 0.645 & 0.853 & \\
QEA6 & 0.647 & 0.853 & \\
QEA $7_{\mathrm{t}+1}$ & 0.725 & 0.845 & \\
QEA ${ }_{\mathrm{t}+1}$ & 0.532 & 0.866 & \\
\hline
\end{tabular}

Source: Author's calculations based on the collected data

\subsection{Test of Hypothesis 1}

To test Hypothesis 1, this research employed the advanced models of directed graphs that underwent two steps. The first step employed the model of directed graph searches with the PC algorithm; whereas the second step applied the advanced model of directed acyclic graphs with SEM parametric estimation. The results are shown in Figure 2 and Table 3.

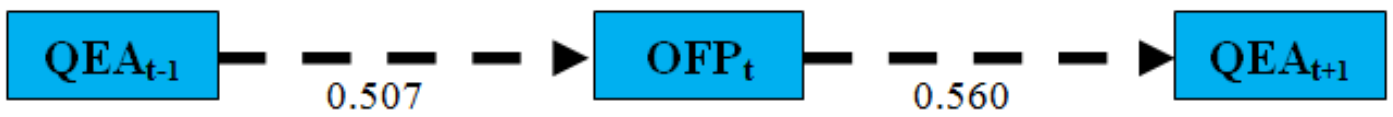

Figure 2. Directed acyclic graph model

Source: Author's calculations based on the research survey

The analysis of chi square $\left(\chi^{2}\right)$ was to test a linear, Normal parametric estimation of the model of directed acyclic graphs. More clearly, it tested the null hypothesis that: $\mathrm{OFP}_{\mathrm{t}}=$ 
$\alpha_{1} \mathrm{QEA}_{\mathrm{t}-1}+\mathrm{e}_{1}$, and $\mathrm{QEA}_{\mathrm{t}+1}=\alpha_{2} \mathrm{OFP}_{\mathrm{t}}+\mathrm{e}_{2}$; where $\mathrm{QEA}_{\mathrm{t}-1}, \mathrm{e}_{1}, \mathrm{e}_{2}$ are jointly Normal and independent, and $\alpha_{1}, \alpha_{2}$ are free estimators. As the figures in Table 3 indicate, the chi square $\left(\chi^{2}\right)$ obtains a value of 0.0176 with $\mathrm{P}_{\chi^{2}}$ of 0.895 ; it cannot reject the null hypothesis, so can conclude that the model of directed acyclic graphs fits very well. As seen in Figure 2 and Table 3, the quality of earnings in year $\mathrm{t}_{\mathrm{t}-1}$ is a determinant of financial performance in year $\mathrm{t}_{\mathrm{t}}$ at the $1 \%$ statistical significance level $(\mathrm{t}=5.885)$ with the 0.507 parametric value; whereas which in turn statistically affects the quality of earnings in year ${ }_{t+1}$ at the $1 \%$ significance level $(t=13.497)$ with the 0.560 parametric estimator. Those empirical evidences provide statistical support for Hypothesis 1 that: the quality of preceding earnings determines current financial performance that in turn improves the quality of the following earnings. In the comparison of these links, both the influential magnitudes are quite the same.

Table 3. Directed graphs results

\begin{tabular}{c|c|c|c|c|c|c|c}
\hline Causes & Effects & Edge coefficients & SE & $\mathrm{t}$ & $\mathrm{P}_{\mathrm{t}}$ & $\chi^{2}$ & $\mathrm{P}_{\chi^{2}}$ \\
\hline QEA $_{\mathrm{t}-1}$ & $\mathrm{OFP}_{\mathrm{t}}$ & 0.507 & 0.086 & 5.885 & 0.000 & \multirow{2}{*}{0.0176} & \multirow{2}{*}{0.895} \\
OFP $_{\mathrm{t}}$ & QEA $_{\mathrm{t}+1}$ & 0.560 & 0.042 & 13.497 & 0.000 & & \\
\hline
\end{tabular}

Source: Author's calculations based on the collected data

\subsection{Test of Hypothesis 2}

To test Hypothesis 2, this research undertook six equations based on Baron and Kenny (1986). Then it was based on Sobel (1982) to estimate the intervenient effects of organizational reputation. The findings are exhibited in Tables 4 and 5. As shown in Table 4, Fs of the models ranged from 77.695 to $194.757\left(\mathrm{P}_{\mathrm{f} . \mathrm{S}}\right.$ of the models all $\left.<1 \%\right)$, which show all the models fit very well. Additionally, earnings quality in year $\mathrm{t}_{-1}$ positively affects organizational reputation in year $\left(\right.$ Model $1, \beta=0.102, \mathrm{P}<5 \%, \mathrm{R}^{2}=0.764$ ) that in turn

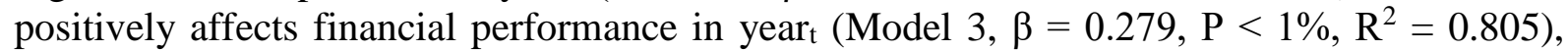
which is positively related to earnings quality in yeart-1 (Model $2, \beta=0.233, \mathrm{P}<1 \%, \mathrm{R}^{2}=$ 0.791). In the comparison of Models 2 and 3, the positive effect of earnings quality in yeart 1 on financial performance in year ${ }_{t}$ in Model 2 becomes weaker in Model $3(\beta=0.233, \mathrm{P}<1 \%$ in Model 2 versus $\beta=0.204, \mathrm{P}<5 \%$ in Model 3). Furthermore, financial performance in year ${ }_{t}$ positively affects organizational reputation in year $_{t+1}$ (Model $4, \beta=0.172, \mathrm{P}<1 \%, \mathrm{R}^{2}=$ 0.838 ), which in turn positively impacts earnings quality in year ${ }_{t+1}$ (Model $6, \beta=0.283, \mathrm{P}<$

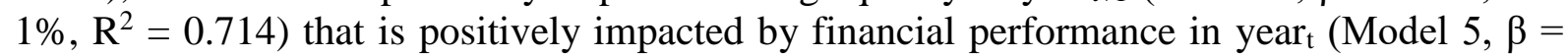
$0.117, \mathrm{P}<5 \%, \mathrm{R}^{2}=0.695$ ). In the comparison of Models 5 and 6 , the positive effect of financial performance in year ${ }_{t}$ on earnings quality in year ${ }_{t+1}$ in Model 5 becomes insignificant in Model 6 ( $\beta=0.117, \mathrm{P}<5 \%$ in Model 5 versus $\beta=0.068, \mathrm{P}>10 \%$ in Model 6$)$. These above discussed results can support Hypothesis 2; this research however continued to test the statistical significance of mediating effects applying Sobel's (1982) procedures.

The results are illustrated in Table 5. The results show organizational reputation in

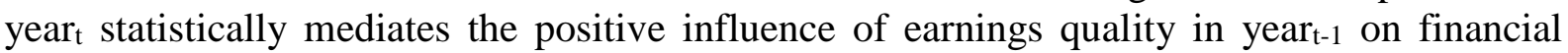
performance in year ${ }_{\mathrm{t}}\left(\mathrm{t}_{\text {indirect }}=2.025\right.$, Std. error $\left.=0.014, \mathrm{P}<5 \%\right)$. However, organizational reputation in year $\mathrm{t}_{+1}$ statistically mediates the positive effect of financial performance in year $\mathrm{r}_{\mathrm{t}}$ on the quality of earnings in year $\mathrm{t}_{+1}\left(\mathrm{t}_{\text {indirect }}=2.569\right.$, Std. error $\left.=0.019, \mathrm{P}<1 \%\right)$. Overall, this empirical evidence offer statistical support for Hypothesis 2 that: current organizational reputation partially mediates the causal link from prior earnings quality to current financial performance, but it fully intervenes in the causal connection from current financial performance to subsequent earnings quality, which makes a vicious circle. 
INTERDISCIPLINARY APPROACH TO ECONOMICS AND SOCIOLOGY

Table 4. Regression results

\begin{tabular}{|c|c|c|c|c|c|c|}
\hline \multirow{2}{*}{ Explanatory variables } & \multicolumn{6}{|c|}{ Explained variables } \\
\hline & $\mathrm{ORE}_{\mathrm{t}}(1)$ & $\mathrm{OFP}_{\mathrm{t}}(2)$ & $\mathrm{OFP}_{t}(3)$ & $\mathrm{ORE}_{\mathrm{t}+1}(4)$ & $\mathrm{QEA}_{\mathrm{t}+1}(5)$ & $\mathrm{QEA}_{\mathrm{t}+1}(6)$ \\
\hline Intercept & $0.440^{* * *}$ & 0.125 & -2.793 & 0.090 & $-2.619^{* * *}$ & $-2.644^{* * *}$ \\
\hline $\mathrm{FSI}_{\mathrm{t}}$ & $0.179^{* * *}$ & $0.163^{* * * *}$ & $0.113^{*}$ & & & \\
\hline $\mathrm{FLI}_{\mathrm{t}}$ & $0.184^{* * *}$ & 0.048 & -0.004 & & & \\
\hline $\mathrm{FLE}_{\mathrm{t}}$ & $0.325^{* * *}$ & $0.253^{* * *}$ & $0.163^{* * *}$ & & & \\
\hline $\mathrm{FCI}_{\mathrm{t}}$ & $0.112^{* *}$ & $0.423^{* * *}$ & $0.392^{* * *}$ & & & \\
\hline $\mathrm{FSI}_{\mathrm{t}+1}$ & & & & $0.295^{* * *}$ & $0.136^{* *}$ & 0.052 \\
\hline $\mathrm{FLI}_{\mathrm{t}+1}$ & & & & $0.111^{* *}$ & $0.120^{*}$ & 0.089 \\
\hline $\mathrm{FLE}_{\mathrm{t}+1}$ & & & & $0.272^{* * * *}$ & $0.217^{* * *}$ & $0.140^{* *}$ \\
\hline $\mathrm{FCI}_{\mathrm{t}+1}$ & & & & $0.100^{*}$ & $0.147^{* *}$ & $0.119^{* *}$ \\
\hline $\mathrm{QEA}_{\mathrm{t}-1}$ & $0.102^{* *}$ & $0.233^{* * *}$ & $0.204^{* *}$ & & & \\
\hline $\mathrm{OFP}_{\mathrm{t}}$ & & & & $0.172^{\text {*** }}$ & $0.117^{* *}$ & 0.068 \\
\hline $\mathrm{ORE}_{\mathrm{t}}$ & & & $0.279^{* * *}$ & & & \\
\hline $\mathrm{ORE}_{\mathrm{t}+1}$ & & & & & & $0.283^{\text {*** }}$ \\
\hline $\mathrm{R}^{2}$ & 0.764 & 0.791 & 0.805 & 0.838 & 0.695 & 0.714 \\
\hline $\mathrm{F}$ & 121.409 & 141.892 & 128.390 & 194.757 & 85.848 & 77.695 \\
\hline $\mathrm{P}_{\mathrm{f}}$ & $<1 \%$ & $<1 \%$ & $<1 \%$ & $<1 \%$ & $<1 \%$ & $<1 \%$ \\
\hline
\end{tabular}

*** 1\%;* 5\%; *10\% Significance

Source: Author's calculations based on the collected data

Table 5. Mediating results

\begin{tabular}{c|c|c|c|c|c}
\hline Mediators & Causal variables & Outcome variables & $t_{\text {indirect }}$ & Std. errors & $\mathrm{P}_{\mathrm{t}}$ \\
\hline $\mathrm{ORE}_{\mathrm{t}}$ & $\mathrm{QEA}_{\mathrm{t}-1}$ & $\mathrm{OFP}_{\mathrm{t}}$ & 2.025 & 0.014 & 0.043 \\
$\mathrm{ORE}_{\mathrm{t}+1}$ & $\mathrm{OFP}_{\mathrm{t}}$ & $\mathrm{QEA}_{\mathrm{t}+1}$ & 2.569 & 0.019 & 0.009 \\
\hline
\end{tabular}

Source: Author's calculations based on the collected data

\section{Discussion and conclusions}

This research has examined the vicious link between earnings quality and financial performance, considering the intervenient role of organizational reputation. Previous researchers have recommended that earnings quality is both an antecedent and a consequence of financial performance in the way that is related to managerial behaviour (e.g. Dechow et al., 1995; Lee et al., 2006; Tabassum et al., 2014; Leggett et al., 2016). Furthermore, some research suggested it is necessary to integrate missing variables into research models (e.g. Surroca et al., 2010; Latif et al., 2017; Huynh, 2018). For the vicious connection between earnings quality and financial performance, an omitted variable could be organizational reputation. However, prior related studies have neither focused on the direction of causation nor established the mediating role of organizational reputation within that vicious relation. This study offers an exposition on the vicious linkage between earnings quality and financial performance by analyzing the mediation of organizational reputation. Grounded on the instrumental stakeholder and slack resources views, discussions in this research were developed to explicate that ethical companies are well-reputed to their stakeholders for their disclosures that likely improve organizational reputation, the importance of which is to gain competitive advantages and so enhance upcoming financial performance. Then the financial performance provides needed resources for activities maintaining and improving 
organizational reputation in the future. Highly reputable companies tend to control managerial opportunism closely and as a result, improve earnings quality.

This research contributes to extant knowledge on the complex links among earnings quality, financial performance and organizational reputation in several ways. The first objective of this research was to investigate the vicious linkage between earnings quality and financial performance. The findings demonstrated that the association between earnings quality and financial performance is developed in a vicious circle, where the quality of prior earnings is originally a cause of financial performance, consistent with the empirical evidence in developed countries (see Taylor \& Xu, 2010) and also in developing countries (see Tabassum et al., 2014) that in turn affects the quality of subsequent earnings, as statistically documented in Western economies (see Hammond \& Slocum, 1996; Lu, 2013). Therefore, this research underlines the significance of high earnings quality that is an original cause within the vicious link, leading to improved financial performance, which has been neglected by prior research. The second objective of this research was to analyze the intervenient influence of organizational reputation on the relationship between earnings quality and financial performance, focusing on the vicissitude. The analyses discovered that the vicious link between earnings quality and financial performance is conditional upon organizational reputation. Previous research has linked organizational reputation to earnings quality and to financial performance (Luchs et al., 2009; Gatzert, 2015; Martínez-Ferrero \& Garcia-Sanchez, 2016; Liu et al., 2016), but the mediating role of organizational reputation has been ignored. Hence, this research emphasizes the role of organizational reputation in controlling that vicious link. The empirical results show that the existence of organizational reputation makes the direct influence of prior earnings quality on current financial performance decrease and become negligible, whereas makes the direct influence of current financial performance on subsequent earnings quality become insignificant because the whole effect is transmitted to subsequent earnings quality through organizational reputation. It can conclude the mediation of organizational reputation in the link from financial performance to earnings quality is stronger than that in the opposite direction. The findings provide a more comprehensive understanding of the intricate links among earnings quality, financial performance and organizational reputation for business executives who had better notice that ethical behaviour in accounting is very important to the survival of companies and is related to the organizational reputation that is a resource of competitive advantages leading to superior financial performance. Therefore, business executives should pay much attention to ethics in accounting which will produce earning reports with higher quality that help to develop stakeholders' confidence; so eventually obtain good financial performance. Some of the results are consistent with those in both developed and developing markets; therefore the empirical findings conducted in Vietnam might be internationally applied.

\section{References}

Ali, R., Lynch, R., Melewar, T. C., \& Jin, Z. (2015). The moderating influences on the relationship of corporate reputation with its antecedents and consequences: A metaanalytic review. Journal of Business Research, 68(5), 1105-1117.

Almahrog, Y., Marai, A., \& Knežević, G. (2016). Earnings management and its relations with corporate social responsibility. Facta Universitatis, Series: Economics and Organization, 12(4), 347-356.

Baron, R. M., \& Kenny, D. A. (1986). The moderator-mediator variable distinction in social psychological research: Conceptual, strategic, and statistical considerations. Journal of personality and social psychology, 51(6), 1173-1182. 
Berrone, P., Surroca, J., \& Tribó, J. A. (2007). Corporate ethical identity as a determinant of firm performance: A test of the mediating role of stakeholder satisfaction. Journal of Business Ethics, 76(1), 35-53.

Blajer-Golebiewska, A. (2014). Corporate reputation and economic performance: The evidence from Poland. Economics \& Sociology, 7(3), 194-207.

Blajer-Gołębiewska, A. \& Kozłowski, A. (2017). Financial determinants of corporate reputation: A short-term approach. Managerial Economics, 17(2), 179-201.

Cao, Y., Myers, L. A., \& Omer, T. C. (2012). Does company reputation matter for financial reporting quality? Evidence from restatements. Contemporary Accounting Research, 29(3), 956-990.

Charitou, A., Lambertides, N., \& Trigeorgis, L. (2007). Earnings quality and financial per formance. In European Accounting Congress.

Choi, B. B., Lee, D., \& Park, Y. (2013). Corporate Social Responsibility, Corporate Governance and Earnings Quality: Evidence from K orea. Corporate Governance: An International Review, 21(5), 447-467.

Dechow, P., Ge, W., \& Schrand, C. (2010). Understanding earnings quality: A review of the proxies, their determinants and their consequences. Journal of accounting and economics, 50(2-3), 344-401.

Dechow, P. M., Sloan, R. G., \& Sweeney, A. P. (1995). Detecting earnings management. Accounting review, 70(2), 193-225.

DeFond, M. L., \& Park, C. W. (1997). Smoothing income in anticipation of future earnings. Journal of Accounting and Economics, 23(2), 115-139.

Du, Q., \& Shen, R. (2018). Peer performance and earnings management. Journal of Banking \& Finance, 89, 125-137.

Dut, V.V. (2015). The effects of local business environments on smes' performance: empirical evidence from the Mekong delta. Asian Academy of Management Journal, 20(1), 101112.

Ferry, B. G., Adebimpe, O. U., George, T. P., \& Lenu, G. W. (2017). Corporate reputation and earnings quality of listed firms in Nigeria. Journal of Research in Business and Management, 5(4), 14-22.

Fich, E. M., \& Shivdasani, A. (2007). Financial fraud, director reputation, and shareholder wealth. Journal of Financial Economics, 86(2), 306-336.

Fischer, P. E., \& Verrecchia, R. E. (2000). Reporting bias. The Accounting Review, 75(2), 229-245.

Francis, J., LaFond, R., Olsson, P. M., \& Schipper, K. (2004). Costs of equity and earnings attributes. The accounting review, 79(4), 967-1010.

Gaio, C., \& Raposo, C. (2011). Earnings quality and firm valuation: international evidence. Accounting \& Finance, 51(2), 467-499.

Gaio, C., \& Raposo, C. C. (2014). Corporate governance and earnings quality: International evidence. Journal of Accounting and Finance, 14(3), 52-74.

Gatzert, N. (2015). The impact of corporate reputation and reputation damaging events on financial performance: Empirical evidence from the literature. European Management Journal, 33(6), 485-499.

Grasso, L. P., Tilley, P. A., \& White, R. A. (2009). The ethics of earnings management: Perceptions after Sarbanes-Oxley. Management Accounting Quarterly, 11(1), 45-69.

Graham, M. E., \& Bansal, P. (2007). Consumers' willingness to pay for corporate reputation: the context of airline companies. Corporate reputation review, 10(3), 189-200.

Hair, J.F., Black, W.C., Babin, B.J., Anderson, R.E., \& Tatham, R.L. (2012). Multivariate Data Analysis. Ed, New Jersey: Pearson Prentice Hall, USA. 
Hammond, S. A., \& Slocum, J. W. (1996). The impact of prior firm financial performance on subsequent corporate reputation. Journal of Business Ethics, 15(2), 159-165.

Huynhб Q.L. (2015). The Mutual Relationship Between Corporate Governance and Management Accounting: Which Occurs First?. American Journal of Applied Sciences, 12(6), 403-410.

Huynh, Q. L. (2018). Earnings Quality with Reputation and Performance. Asian Economic and Financial Review, 8(2), 269-278.

Jackson, A. R. (2005). Trade generation, reputation, and sell-side analysts. The Journal of Finance, 60(2), 673-717.

Johnson, W. C., Xie, W., \& Yi, S. (2014). Corporate fraud and the value of reputations in the product market. Journal of Corporate Finance, 25, 16-39.

Kaplan, S. E., \& Ravenscroft, S. P. (2004). The reputation effects of earnings management in the internal labor market. Business Ethics Quarterly, 14(3), 453-478.

Kinney Jr, W. R., \& McDaniel, L. S. (1989). Characteristics of firms correcting previously reported quarterly earnings. Journal of accounting and economics, 11(1), 71-93.

Latif, K., Bhatti, A. A., \& Raheman, A. (2017). Earnings quality: A missing link between corporate governance and firm value. Business \& Economic Review, 9(2), 255-280.

Lee, C. W. J., Li, L. Y., \& Yue, H. (2006). Performance, growth and earnings management. Review of Accounting Studies, 11(2-3), 305-334.

Le, Y., Hollenhorst, S., Harris, C., McLaughlin, W., \& Shook, S. (2006). Environmental management: A study of Vietnamese hotels. Annals of Tourism Research, 33(2), 545567.

Leggett, D. M., Parsons, L. M., \& Reitenga, A. L. (2016). Real Earnings Management and Subsequent Operating Performance. IUP Journal of Operations Management, 15(4)6 732.

Lu, X. (2013). The Impact of Corporate Reputation on Earnings Management Decisions (Doctoral dissertation, University of Durham 2013.).

Luchs, C., Stuebs, M., \& Sun, L. (2009). Corporate Reputation and Earnings Quality. Journal of Applied Business Research, 25(4), 47-54.

Liu, X., Vredenburg, H., \& Steel, P. (2016). Determinants and moderators of corporate reputation: A meta-analysis. In Academy of Management Proceedings (Vol. 2016, No. 1, p. 12980). Briarcliff Manor, NY 10510: Academy of Management.

Lyimo, G. D. (2014). Assessing the measures of quality of earnings: Evidence from India. European Journal of Accounting Auditing and Finance Research, 2(6), 17-28.

$\mathrm{Ma}$, H. (2000). Competitive advantage and firm performance. Competitiveness Review: An International Business Journal, 10(2), 15-32.

Machdar, N. M., Adler H.M.D.R., \& Murwaningsari, E. (2017). The effects of earnings quality, conservatism, and real earnings management on the company's performance and information asymmetry as a moderating variable. International Journal of Economics and Financial Issues, 7(2), 309-318.

Martínez-Ferrero, J. (2014). Consequences of financial reporting quality on corporate performance: Evidence at the international level. Estudios de Economía 41(1), 49-88.

Martínez-Ferrero, J., Banerjee, S., \& García-Sánchez, I. M. (2016). Corporate social responsibility as a strategic shield against costs of earnings management practices. Journal of Business Ethics, 133(2), 305-324.

Martínez-Ferrero, J., \& Garcia-Sanchez, I.M. (2016). Corporate Reputation as a Consequence of Financial Reporting Quality. International Management \& Economics Frontiers, $1(1), 45-43$.

Pagalung, G., \& Sudibdyo, B. (2018). The Determinant Factors of Earnings Quality and Economic Consequences. EKUITAS (Jurnal Ekonomi dan Keuangan), 16(1), 105-122. 
Perotti, P., \& Wagenhofer, A. (2014). Earnings quality measures and excess returns. Journal of business finance \& accounting, 41(5-6), 545-571.

Riahi-Belkaoui, A., \& Pavlik, E.L. (1992). Accounting for Corporate Reputation. Quorum Books, Greenwood Publishing Group, Connecticut: USA.

Roberts, P. W., \& Dowling, G. R. (2002). Corporate reputation and sustained superior financial performance. Strategic Management Journal, 23(12), 1077-1093.

Rodriguez-Ariza, L., Martínez-Ferrero, J., \& Bermejo-Sánchez, M. (2016). Consequences of earnings management for corporate reputation: Evidence from family firms. Accounting Research Journal, 29(4), 457-474.

Russo, M. V., \& Fouts, P. A. (1997). A resource-based perspective on corporate environmental performance and profitability. Academy of Management Journal, 40(3), 534-559.

Sarun, A. (2016). Corporate Governance, Earnings Quality and Firm Value: Evidence from Malaysia (Doctoral dissertation, Victoria University).

Schwab, K. (2017). The global competitiveness report 2017-2018. Geneva: World Economic Forum, Switzerland.

Sobel, M. E. (1982). Asymptotic confidence intervals for indirect effects in structural equation models. Sociological methodology, 13, 290-312.

Surroca, J., Tribó, J. A., \& Waddock, S. (2010). Corporate responsibility and financial performance: The role of intangible resources. Strategic management journal, 31(5), 463-490.

Tabassum, N., Kaleem, A., \& Nazir, M. S. (2014). Real earnings management and future performance. Global Business Review, 16(1), 21-34.

Taylor, G. K., \& Xu, R. Z. (2010). Consequences of real earnings management on subsequent operating performance. Research in Accounting Regulation, 22(2), 128-132.

Teoh, S. H., Welch, I., \& Wong, T. J. (1998). Earnings management and the long-run market performance of initial public offerings. The Journal of Finance, 53(6), 1935-1974.

Warrad, L. H. (2017). The Influence of Leverage and Profitability on Earnings Quality: Jordanian Case. International Journal of Academic Research in Business and Social Sciences, 7(10), 62-81.

Zhatkin, Y., Gurvitš, N., \& Strouhal, J. (2017). Addressing ethical matters in Ukrainian accounting practice. Economics \& Sociology, 10(3), 167-178. 